\section{Different behaviour between autotrophic and heterotrophic Galdieria sulphuraria (Rhodophyta) cells to nitrogen starvation and restoration. Impact on pigment and free amino acid contents}

\author{
Giovanna Salbitani, Simona Carfagna \\ Department of Biology, University of \\ Naples Federico II, Napoli, Italy
}

\begin{abstract}
The unicellular red alga Galdieria sulphuraria is a polyextremophilic organism with a metabolic flexibility to grow autotrophically or heterotrophically. Galdieria can also produce and accumulate biotechnologically attractive products such as pigments (phycocyanin) and proteins. In this research we studied the effects of nitrogen starvation and its subsequent restoration on pigment and free amino acid contents both in photoautotrophic and heterotrophic cells. Following the nitrogen starvation, the levels of the primary photosynthetic pigments decreased both in autotrophic and heterotrophic cells, except for the chlorophyll $a$ marginally diminished in heterotrophic cells. Ammonium supply to G. sulphuraria $\mathrm{N}$ starved cells caused a significant increase of total chlorophylls both in autotrophic and heterotrophic cells. It was observed how such increase was more rapid and marked in heterotrophic cells than in the autotrophic ones. Under N starvation, phycocyanin contents decreased in both autotrophic and in heterotrophic cells; however, after a time-lapse of 24 hours, they resulted significantly higher in heterotrophic cells. In Galdieria sulphuraria, like in other microalgae, free amino acid contents were profoundly dependent on nitrogen status of the cells but heterotrophic cells maintained much higher levels, especially of glutamate, respect to autotrophic ones. In general, cells grown in the presence and absence of light showed different responses toward $\mathrm{N}$ availability; in particular heterotrophic cells seemed to respond quicker to the ammonium restoration compared to autotrophic ones.
\end{abstract}

\section{Introduction}

Among abiotic factors capable of influencing the algal growth, the availability of nutrients is one of the most important, along with light and temperature. ${ }^{1}$ Microalgae, as well as plants, need macro- and micronutrients for their growth. Macronutrients, such as nitrogen $(\mathrm{N})$, are required in larger quantities; in fact, they represent structural components of cells and are important for osmoregulation. Nutrient deficiency, in particular nitrogen, affects many aspects of plants and microalgae physiology. ${ }^{2}$ General symptoms of $\mathrm{N}$ deficiency, like the decreasing growth rate, the decline in cell protein and in pigment contents, have been all well described in microalgae. ${ }^{2-6}$ Generally, microalgae and cyanobacteria maintain a restricted ability to preserve the photosynthetic functions during $\mathrm{N}$ starvation. ${ }^{3,7}$ Also, in microalgae, the effects due to the lack of a nutrient can be rapid (hours) and mediated by an oxidative imbalance. ${ }^{8-9}$

The unicellular red algae Galdieria sulphuraria is a member of the Cyanidiales, polyextremophilic microalgae thriving in highly acidic environments ( $\mathrm{pH} 0.05-5.00)$ with elevated temperatures up to $56{ }^{\circ} \mathrm{C}$, where Galdieria is the predominant genus. ${ }^{10}$ The horizontally acquired genes of bacterial and archaea, found in the nuclear genome of $G$. sulphuraria, explain the unusual ability to survive in such extreme habitats. For example, the horizontal acquisition of several bacterial ion pumps is recognized to provide G. sulphuraria with the ability to maintain neutral cytosolic $\mathrm{pHs}$ despite the highly acid environment, as well as salinity and metal resistance. ${ }^{11-12}$ Besides, many metabolite transporters are encoded in the genome of G. sulphuraria, including amino acid and polyamine; it is likely that Galdieria sulphuraria has a strong tolerance to grow in N limited environments. G. sulphuraria digests at least 27 sugars and up to 50 carbon sources as nutrients and metabolizes them using pathways that are lost in today's photosynthetic eukaryotes. $^{13}$

Interestingly, Cyanidium caldarium and Cyanidioschyzon merolae, also belonging to the group of Cyanidiales, are strictly photoautotrophic and cannot grow in the absence of light. G. sulphuraria can be grown in both heterotrophic and photoautotrophic conditions due to its metabolic versatility. That is, G. sulphuraria possess the uptake systems for organic substrates but also retain the photosynthetic apparatus.

In Cyanidiales, the pigments apparatus combines many eukaryotic and cyanobacteria properties. ${ }^{14}$ In fact, in cyanobacteria and in red algae, phycobiliproteins, assembled in phycobilisomes, complete the lightharvesting complexes. Among phycobiliproteins, the blue pigment of C-phycocyanin (C-PC) has recently attracted the
Correspondence: Simona Carfagna, Dipartimento di Biologia, Università Federico II di Napoli, via Cinthia, 80126 Napoli, Italy. Tel.: +39.081.2538559.

E-mail: simcarfa@unina.it.

Key words: Amino acids, ammonium, Galdieria sulphuraria, N starvation, pigments.

Contributions: The authors contributed equally.

Conflict of interest: The authors declare no conflict of interest.

Funding: The work was supported by the program STAR-2018 (Sostegno Territoriale alle Attività di Ricerca) funded by University of Naples Federico II and Compagnia di San Paolo.

Received for publication: 2 April 2020.

Accepted for publication: 2 June 2020.

This work is licensed under a Creative Commons Attribution-NonCommercial 4.0 International License (CC BY-NC 4.0).

${ }^{C}$ Copyright: the Author(s), 2020

Licensee PAGEPress srl, Italy

International Journal of Plant Biology 2020; 11:8567 doi:10.4081/pb.2020.8567

attention of many researchers for its excellent properties and its likely use in many biotechnological applications. ${ }^{10,15-16}$ Galdieria sulphuraria C-PC is not only very resistant to high temperature but can also be used as a food additive colouring agent, ${ }^{17}$ and as a natural antioxidant ingredient $^{18}$ and for others biotechnological purposes. ${ }^{19-20}$

The growth and the biochemical composition of microalgae are extremely sensitive to alterations in physical and chemical parameters of the culture medium. For example, the photosynthetic pigment levels vary depending on the cultivation conditions such as light regime, temperature, inorganic carbon content, medium $\mathrm{pH}$ or stress. ${ }^{21-25}$ In fact, by manipulating culture conditions, it is possible to get higher or lower concentrations of a certain pigment. $^{24,26}$ The $\mathrm{N}$ natural resources for autotrophic organisms are ammonium and/or nitrate. The absorbed nitrate is firstly reduced to ammonium and then assimilated into glutamine through the glutamine synthetase enzymes. Once assimilated as glutamine, nitrogen is transferred to 2-oxoglutarate to form glutamate through the glutamate synthase, and further utilized to form various nitrogen organic compounds. Although the matter is still debated, glutamate dehydrogenase could also be used in 
the nitrogen assimilation. ${ }^{27}$ Galdieria sulphuraria, as all members of Cyanidiales, can assimilate nitrogen from the culture medium as nitrate or ammonium salts. Therefore, the main nitrogen source in acidic hot springs is the ammonium and nitrate assimilation rarely occur in these environments. ${ }^{28}$ The effect of nitrogen starvation on photosynthetic pigments was previously considered in green algae $e^{29-32}$ and in cyanobacteria. ${ }^{3}$ In Cyanidiales, only the effects of a long-term $\mathrm{N}$ starvation (10 days) in autotrophic cells had been taken into account by. ${ }^{14}$ The aim of this paper is to investigate and clarify the short-term effects of $\mathrm{N}$ starvation $(24 \mathrm{~h})$ and its subsequent resupply (24h) on pigment and free amino acid contents in both autotrophic and heterotrophic cells of G. sulphuraria.

\section{Materials and Methods}

\section{Algal Strains and Growth Conditions}

Experiments were performed with pure cultures of the red algae Galdieria sulphuraria (strain 011) from the ACUF collection of the Department of Biology of the University of Federico II, Naples, Italy (http://www.biologiavegetale.unina.it/acuf. $\mathrm{html}$ ). Cells were grown in batches containing $1 \mathrm{~L}$ of Allen medium ${ }^{33}$ with $10 \mathrm{mM}$ $\left(\mathrm{NH}_{4}\right)_{2} \mathrm{SO}_{4}$ as nitrogen source. They were placed in a thermostatic chamber (Angelantoni $\mathrm{CH}$ 770) under continuous irradiance $90 \mu \mathrm{mol} \mathrm{m}{ }^{-2} \mathrm{~s}^{-1}$ photons at $38 \pm$ $1{ }^{\circ} \mathrm{C}$. The $\mathrm{pH}$ was set at 1.5 and controlled daily. Carbon dioxide was supplemented by filtered air blowing into the medium. Furthermore, each batch containing the heterotrophic cultures was wrapped with aluminum foil to ensure that the cultivation took place in the dark, and organic carbon was supplemented with $2 \%$ (w/v) glycerol.

In the experiments of $\mathrm{N}$ starvation, the cells were harvested during the logarithmic phase of growth (culture $\mathrm{OD}_{800} \sim 1.0$ ) by low speed centrifugation at $4000 \times g$ for 10 min and washed twice with N-free Allen's medium where $\left(\mathrm{NH}_{4}\right)_{2} \mathrm{SO}_{4}$ was omitted. Then, the supernatant was removed, and the algal pellets were re-suspended in $\mathrm{N}$ free Allen's medium and cultured up to $24 \mathrm{~h}$. The effects of the ammonium addition to the nutrient solution of $\mathrm{N}$ starved cells for 24 hours were analysed supplying $\left(\mathrm{NH}_{4}\right)_{2} \mathrm{SO}_{4}$ at a final concentration of $10 \mathrm{mM}$.

\section{Extraction and determination of amino acids}

Samples of the cell suspensions $(10 \mathrm{~mL})$ were collected at given times by centrifuga- tion $(4000 \times g$ for $15 \mathrm{~min})$. The packed cells were treated with $1 \mathrm{~mL}$ of cold $80 \%$ ethanol and vortexed. The amino acids were extracted for $10 \mathrm{~min}$ at $4^{\circ} \mathrm{C}$ and finally clarified by centrifugation. The supernatant was filtered using Waters Sep-Pak Cartridges C18 light (Milan, Italy), and utilized for amino acid analysis as previously described. ${ }^{34}$ Quantification of glutamic acid (Glu), asparagine (Asn) and glutamine (Gln) were made against a relative calibration curve and expressed as $\mu \mathrm{mol} \mathrm{mL}^{-1} \mathrm{PCV}$.

\section{Spectroscopic estimation of pig- ments in the crude extracts}

Chlorophyll (Chl) ( $a$ and total) were extracted with $\mathrm{N}, \mathrm{N}$-dimethylformamide. The Chl ( $a$ and total) contents were estimated spectrophotometrically at 647 and 665 $\mathrm{nm}$ according to Carfagna et al. ${ }^{35}$ The C-PC contents were estimated as previously described. ${ }^{10}$

\section{Packed cell volume (PCV) determi- nation}

Packed Cell Volume (PCV) was measured by centrifuging a known aliquot of cell suspension in a hematocrit tube at $4000 \mathrm{~g}$ for $5 \mathrm{~min}$ as previously reported. ${ }^{34}$

\section{Statistical analyses}

Experimental data analysis was carried out using the Sigmaplot 14 software. Data of the mean \pm standard deviation of three independent experiments were also presented. The statistical analysis was performed by one-way analysis of variance (ANOVA) with a Tukey post ad hoc test to determine differences between autotrophic and heterotrophic conditions.

\section{Results and Discussion}

After carbon, nitrogen is the most essential nutrient for plant and algae since it contributes directly to biomass production. The availability of $\mathrm{N}$ affects the photosynthesis activity in a way that low quantities of nitrogen compromises the structure of the photosystems in terms of protein and photosynthetic pigment contents. In this study, we consider and compare the shortterm effect of $\mathrm{N}$ starvation and restoration in G. sulphuraria cells both in autotrophic and in heterotrophic growth condition. Galdieria cells, grown in a complete Allen medium and kept in the light (autotrophic control cells) showed similar contents of Chl $a\left(3.9 \pm 0.2 \mu \mathrm{g} \mu \mathrm{L}^{-1} \mathrm{PCV}\right)$ and total $\mathrm{Chl}$ $\left(5.6 \pm 0.4 \mu \mathrm{g} \mu \mathrm{L}^{-1} \mathrm{PCV}\right)$ if related to heterotrophic control cells (Chl $a, 2.7 \pm 0.3 \mu \mathrm{g}$ $\mu \mathrm{L}^{-1} \mathrm{PCV}$; total Chl, $\left.4.9 \pm 0.3 \mu \mathrm{g} \mu \mathrm{L}^{-1} \mathrm{PCV}\right)$ (Figure 1A-B). Most Galdieria strains lose

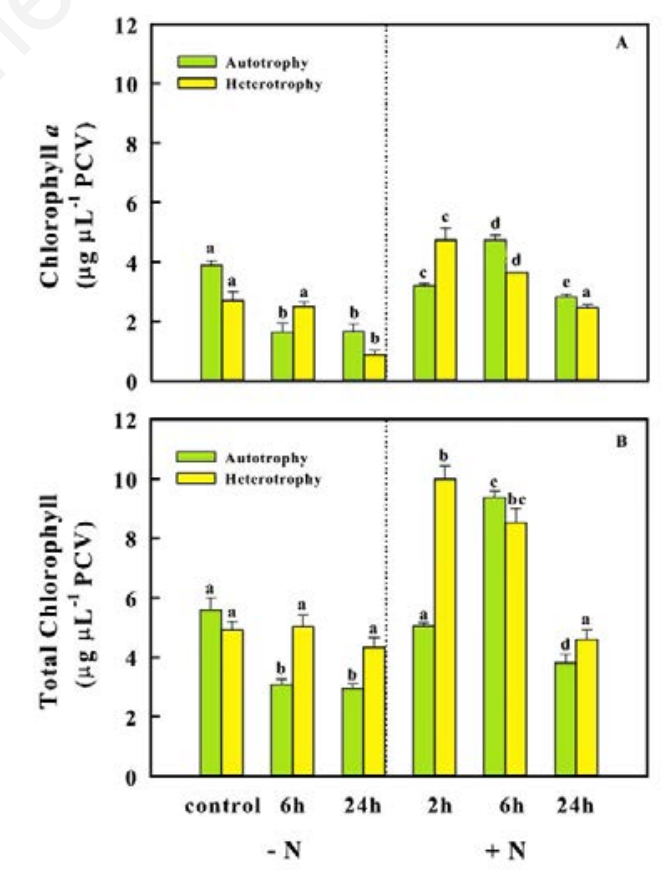

Figure 1. Chl $a$ (A) and total Chl contents (B) as a function of $\mathrm{NH}_{4}^{+}$availability (N) in Galdieria sulphuraria cells growth in autotrophy and heterotrophy. On the left side, it is indicated the data referring to the nitrogen starvation $(-\mathrm{N})$, while on the right hand side, the data after nitrogen addition $(+N)$, indicated by the dotted line. Error bars represent standard deviation of the mean $(n=3)$. The same letters above each bar, within the same graph, indicate non-significant differences ( $P \leq 0.05$, ANOVA, Tukey's multiple comparison). 
their pigmentation when they are heterotrophically grown. ${ }^{13,36}$ Unlike the others, Galdieria sulphuraria (strain ACUF 011) does not bleach under heterotrophy since Chls levels are not considerably different between auto- and heterotrophic cells. Anyway, total Chl decreased in autotrophic cells under $\mathrm{N}$ starvation while it remained almost unchanged in heterotrophic cells (Figure 1B) with Chl a content strongly decreased already after 24 hours of $\mathrm{N}$ deprivation (Figure 1A). Ammonium supply, following the $24 \mathrm{~h}$ of $\mathrm{N}$ starvation, caused a significant increase of total $\mathrm{Chl}$ both in autotrophic and heterotrophic cells (Figure 1B). Therefore, the increase in total Chl was observed to be more rapid and marked in heterotrophic cells. In fact, after only two hours from the ammonium supply, Chls were $9.98 \pm 0.5 \mu \mathrm{g} \mu \mathrm{L}^{-1} \mathrm{PCV}$, values significantly higher respect to those of autotrophic cells (Figure 1B). The amount of total Chl was similar in both auto- and heterotrophic cells after six hours from the $\mathrm{N}$ supply and dropped in the following hours (Figure 1B).

Nitrogen assimilation and photosynthetic pigments synthesis are closely linked. The loss of pigments (i.e. chlorophylls, phycobiliproteins) caused by $\mathrm{N}$ starvation is considered, together with cessation of cell division, a general response that occurs in all photoautotrophic organisms. ${ }^{7,31}$ In autotrophic cells, the decrease in Chls level is very harmful as it reduces the ability to capture light and to perform an efficient photosynthesis. Chlorophylls are N-containing-macromolecule and a reduction of their ex-novo synthesis lead to a decrease in the nitrogen demand. Typically, in microalgae, the diminution in Chl content leads to a dramatic change in colour from usual bluegreen to yellow-green. Such phenomenon is referred to as bleaching or chlorosis.

As previously reported by Perez-Garcia et al.,37 photosynthetic pigments in the light-harvesting complex in G. sulphuraria under heterotrophic cultivation were slightly lower than those cultivated with photoautotrophic cultivation. These lower contents have been attributed to the reduction of their synthesis since the energy, in heterotrophic cells, derives from oxidation of the organic substrate and not from photosynthesis.

Our results indicate that generally the pigments decrease under $\mathrm{N}$ deprivation both in autotrophic and heterotrophic cells, but with a different time course and to a different extent. Chl $a$ was rapidly affected in autotrophic cells while marginally decreased in heterotrophic cells in the first 6 hours of starvation. This result suggested that during the $\mathrm{N}$ deprivation the synthesis of the components of the antenna system was preferred over the photosystem reaction centres. It is reasonable to think that these pigments have not only the role of an antenna, and therefore linked to the capture of light for photosynthesis, but they are also used as $\mathrm{N}$ reserve. Also, total Chl, that in the Cyanidiales include chlorophyll $a$ and $d,{ }^{38}$ was more affected by $\mathrm{N}$ starvation in autotrophic cells respect to heterotrophic ones.

In this study also the change in C-PC levels were considered. After $6 \mathrm{~h}$ of $\mathrm{N}$ starvation, C-PC contents decreased significantly $(\mathrm{P} \leq 0.05)$ in autotrophic (from $10.7 \pm 0.5$ to $3.8 \pm 0.2 \mu \mathrm{g} \mu \mathrm{L}^{-1} \mathrm{PCV}$ ) and in heterotrophic cells (from $6.9 \pm 0.07$ to $\left.1.4 \pm 0.2 \mu \mathrm{g} \mu \mathrm{L}^{-1} \mathrm{PCV}\right)$. After 24 hours, CPC continued decreasing $\left(2.7 \pm 0.4 \mu \mathrm{g} \mu \mathrm{L}^{-1}\right.$ $\mathrm{PCV}$ ) while resulted significantly increased in heterotrophic cells reaching the value of $12.3 \pm 1.6 \mu \mathrm{g} \mu \mathrm{L}^{-1} \mathrm{PCV}$. Ammonium addition provoked a sudden increase in C-PC in both cell types. After only two hours from the addition of ammonium, it was noted an increase in C-PC, reaching the value of $8.3 \pm 1.4 \mu \mathrm{g} \mu \mathrm{L}^{-1} \mathrm{PCV}$ in autotrophic cells and $22.4 \pm 1.0 \mu \mathrm{g} \mu \mathrm{L}^{-1} \mathrm{PCV}$ in heterotrophic ones (Figure 2). Therefore, in the following four hours of $\mathrm{N}$ restoration, C-PC continued to increase in the autotrophic cells, stopping in the heterotrophic ones. In the following hours up to 24 hours from the ammonium addition, the concentration of C-PC decreased in in both cells, particularly under heterotrophic condition (Figure 2).

Definitely, N-deprivation also reduced the content of C-PC for all 24 hours in autotrophic cells but only in the first 6 hours in heterotrophic cells. Indeed, in the latter, there was a sharp increase in concentration at the end of the starvation period. The results seem to indicate that $\mathrm{N}$ starvation most affected autotrophic cells, concerning Chls and C-PC, compared to heterotrophic cells. These observations suggested that cells used these $\mathrm{N}$-containing pigments when the intracellular level of nitrogen depleted. Perhaps, these nitrogenous compounds are converted into essential N-containing cell materials such as proteins, nucleic acid, and cell wall materials necessary for the cell growth or the synthesis of polypeptides required for acclimation to the N starvation. ${ }^{14,39}$ Moreover, C-PC could act as a nitrogen store as previously reported by Sloth et al. ${ }^{39}$ while its degradation would be rather for minimising the absorption of excess excitation energy under stress conditions as in cyanobacteria. ${ }^{40}$ In Synechococcus, a C-PC decrease occurs within 8 hours of $\mathrm{N}$ starvation. ${ }^{3}$ Furthermore, the $\mathrm{N}$ deprivation limits Chls and C-PC synthesis since protoporphyrin IX, their common precursor, is a product of ammonium assimilation. $^{21}$

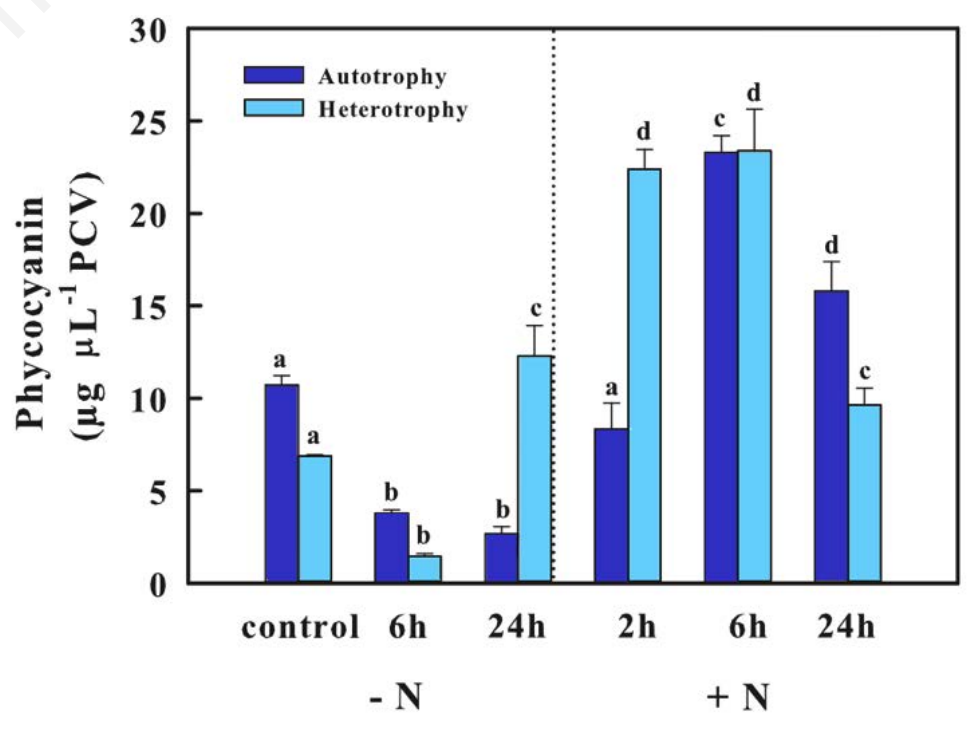

Figure 2. Phycocyanin content ( $\mu \mathrm{g} \mu \mathrm{L}^{-1} \mathrm{PCV}$ ) as a function of $\mathrm{NH}_{4}^{+}$availability $(\mathrm{N})$ in Galdieria sulphuraria cells cultured in autotrophy, and in heterotrophy. On the left side, it is indicated the data referring to the nitrogen starvation $(-\mathrm{N})$, while on the right hand side, the data after nitrogen addition $(+N)$, indicated by the dotted line. Error bars represent standard deviation of the mean $(n=3)$. The same letters above each bar, within the same graph, indicate non-significant differences $(P \leq 0.05$, ANOVA, Tukey's multiple comparison). 
Sinetova et al. ${ }^{14}$ showed relevant changes occurring in the chloroplast ultrastructure in Galdieria sulphuraria photoautotrophic cells under $\mathrm{N}$ deficiency. The chloroplast was reduced, and storage compounds accumulated. The occurrence of storage compounds in the chloroplast could explain the delayed start of nitrogen assimilation, with the addition of ammonium, which occurs in autotrophic cells of G. sulphuraria.

Free amino acid contents in the algal cell is an excellent index of the ability to assimilate the nitrogen just added to the culture. ${ }^{29}$ Typically, in N starved algal cells the content of free amino acids is reduced due to the slowdown of their synthesis. In addition, $\mathrm{N}$-deprived and photosynthesizing algal cells are always very ready to assimilate ammonium as early as the first two hours after $\mathrm{N}$ addition. In this study, Glu and amide levels were different in autotrophic and heterotrophic cells, both under $\mathrm{N}$ starvation and after ammonium restoration (Table 1). The concentration of free Glu resulted much higher in the heterotrophic cells than in the autotrophic ones. Under $\mathrm{N}$ deprivation, Glu did not change in both auto- and heterotrophic cells, but its level was about twice as high in heterotrophic as compared to autotrophic cells. Furthermore, after 2 hours from ammonium supply, Glu decreased in autotrophic cells (from $7.10 \pm 0.67$ to 5.65 $\pm 0.15 \mu \mathrm{mol} \mathrm{mL} \mathrm{m}^{-1} \mathrm{PCV}$ ), while it was about four times higher in the heterotrophic cells than in the autotrophic cells. In the following few hours, Glu contents restored in autotrophic cells while decreased in heterotrophic ones (Table 1).

The concentration of free glutamine (Gln) resulted similar in autotrophic and heterotrophic cells (Table 1). Therefore, after 6 hours of $\mathrm{N}$ starvation, Gln increased in both autotrophic (from $0.74 \pm 0.13$ to $\left.1.93 \pm 0.19 \mu \mathrm{mol} \mathrm{mL}^{-1} \mathrm{PCV}\right)$ and in heterotrophic cells (from $0.67 \pm 0.15$ to $1.80 \pm$ $\left.0.38 \mu \mathrm{mol} \mathrm{mL}{ }^{-1} \mathrm{PCV}\right)$. After 24 hours, Gln resulted almost unchanged at $1.98 \pm 0.56$ $\mu \mathrm{mol} \mathrm{mL} \mathrm{m}^{-1} \mathrm{PCV}$ in autotrophic cells and decreased to $0.70 \pm 0.20 \mu \mathrm{mol} \mathrm{mL}^{-1} \mathrm{PCV}$ in the heterotrophic ones. Nitrogen re-supply increased the Gln content in both autotrophic and heterotrophic cells. After 2 hours of the ammonium supply, Gln doubled (4.48 \pm $\left.0.89 \mu \mathrm{mol} \mathrm{mL} \mathrm{mL}^{-1} \mathrm{PCV}\right)$ in both cell types (1.62 $\pm 0.55 \mu \mathrm{mol} \mathrm{mL}{ }^{-1}$ PCV) (Tab.1). At the end of the experiments, the Gln contents were similar in both conditions (about 7.0 $\mu \mathrm{mol} \mathrm{mL} \mathrm{m}^{-1} \mathrm{PCV}$ ).

$\mathrm{N}$ starvation for 24 hours affected Asn content, which decreased in autotrophic cells (from $2.95 \pm 0.73$ to $1.59 \pm 0.73 \mu \mathrm{mol}$ $\mathrm{mL}^{-1} \mathrm{PCV}$ ) and increased in heterotrophic ones (from $1.16 \pm 0.22$ to $3.31 \pm 0.50 \mu \mathrm{mol}$ $\left.\mathrm{mL}^{-1} \mathrm{PCV}\right)$. However, following the addition of ammonium, asparagine increased significantly in autotrophic cells after 2 hours, while slightly decreased in both cell types in the following hours.

In our experiments, heterotrophic cells seem to respond quickly to the ammonium addition when compared to autotrophic ones. In G. sulphuraria N starved for $24 \mathrm{~h}$, the Gln levels are significantly higher in autotrophic cells than in heterotrophic ones. The high content of Gln in autotrophic cells could exert an inhibiting effect of ammonium uptake as previously reported. ${ }^{29}$ Highaffinity ammonium transport and AMT1.1 expression appear to be subject to downregulation by glutamine. ${ }^{41}$ It is reasonable to suppose that the high content of Gln in autotrophic cells may exert a temporary inhibition of ammonium uptake, explaining the delayed effect ( $2 \mathrm{~h}$ ) of ammonium supply on changing Chl contents. Indeed, in heterotrophic cells, where Gln levels were significantly lower than autotrophic cells, the effects of ammonium addition on metabolite changing took place in a short time.

Among the intracellular free amino acids, Glu is the one that change less marginally, even when cells were exposed to $\mathrm{N}$ deprivation. ${ }^{42}$ In fact, Glu forms a steady cellular pool from which to draw for the synthesis of other amino acids and $\mathrm{N}$ compounds. Its decrease, immediately after the addition of ammonium to autotrophic cells, could indicate the activation of glutamine synthetase enzyme, which uses glutamate as a substrate. After that time, glutamate concentration was promptly restored.

In this regard, it is very interesting to note that cells in heterotrophy had much higher levels of Glu than autotrophic cells. In general, high intracellular levels of Glu may indicate poor ability to assimilate ammonium in the form of Gln. Indeed, heterotrophic cells had a lower total $\mathrm{N}$ content than autotrophic cells, lacking photosystems and proteins related to the photosynthetic activity. ${ }^{17}$ In addition, Glu is a constituent of glutathione together with cysteine and glycine. Cells from heterotrophic cultures of Galdieria sulphuraria and Galdieria phlegrea exhibited high levels of glutathione content; ${ }^{16,17}$ thus, high levels of glutamate could certainly be related to high levels of glutathione found in heterotrophic cells. Glutamate in heterotrophic cells remained high and unchanged after the ammonium supply (2h). However, it significantly decreased after 6 hours from the $\mathrm{N}$ addition. This result could be explained by the activation of the enzyme glutamate dehydrogenase to refurnish of $\alpha$-ketoglutarate the Krebs cycle, a prominent metabolic pathway in cells under heterotrophic growth condition. ${ }^{37}$ Another alternative is that the enzyme glutamate dehydrogenase is involved in detecting the redox status of the cell and as such, it can represent a stress monitoring protein. ${ }^{27}$ It is captivating to note that the asparagine present in cells in heterotrophy condition, to some extent, increased during the $\mathrm{N}$ deprivation. A future study will be conducted to evaluate the activity of phosphoenolpyruvate carboxylase enzyme in these cells, which usually supplies oxoacetate to the Krebs cycle to support the aspartate (Asn precursor) and amino acid synthesis.

Table 1. Changes of free amino acid concentrations in Galdieria sulphuraria, growing in autotrophy and heterotrophy, either under $\mathrm{N}$ starvation or after ammonium addition. The values reported are the average of three separate experiments \pm Standard Error (SE).

\begin{tabular}{|c|c|c|c|c|c|c|c|}
\hline $\begin{array}{l}\text { Growth } \\
\text { condition }\end{array}$ & $\begin{array}{l}\text { Amino Acid } \\
\left(\mathrm{mol} \mathrm{mL} \mathrm{L}^{-1} \mathrm{PCV}\right)\end{array}$ & 0 & $\begin{array}{c}\text { Time }(h)-N \\
6\end{array}$ & 24 & 2 & Time $(\mathrm{h})+\mathrm{N}$ & 24 \\
\hline Autotrophy & $\begin{array}{l}\text { Glu } \\
\text { Asn } \\
\text { Gln }\end{array}$ & $\begin{array}{c}7.10 \pm 0.67 \mathrm{~A}^{\mathrm{ab}} \\
2.95 \pm 0.73 \mathrm{~A}^{\text {ad }} \\
0.74 \pm 0.13^{\mathrm{Aa}}\end{array}$ & $\begin{array}{c}9.39 \pm 0.92^{\mathrm{Aab}} \\
0.84 \pm 0.05^{\mathrm{Ab}} \\
1.93 \pm 0.19^{\mathrm{Ab}}\end{array}$ & $\begin{array}{c}9.21 \pm 0.69^{\text {Aab }} \\
1.59 \pm 0.73^{\text {Aab }} \\
1.98 \pm 0.56^{\text {Aabc }}\end{array}$ & $\begin{array}{l}5.65 \pm 0.15^{\mathrm{Ab}} \\
5.73 \pm 0.38^{\mathrm{Ac}} \\
4.48 \pm 0.89^{\mathrm{Ac}}\end{array}$ & $\begin{array}{c}11.39 \pm 2.01^{\mathrm{Aa}} \\
3.41 \pm 0.47^{\mathrm{Ad}} \\
1.42 \pm 0.34^{\mathrm{Aab}}\end{array}$ & $\begin{array}{l}7.90 \pm 1.14^{\text {Aab }} \\
1.20 \pm 0.23^{\text {Aab }} \\
7.79 \pm 0.48^{\text {Ad }}\end{array}$ \\
\hline Heterotrophy & $\begin{array}{l}\text { Glu } \\
\text { Asn } \\
\text { Gln }\end{array}$ & $\begin{array}{c}16.97 \pm 1.41^{\mathrm{Ba}} \\
1.16 \pm 0.22 \mathrm{~B}^{\mathrm{ac}} \\
0.67 \pm 0.15^{\mathrm{Aa}}\end{array}$ & $\begin{array}{c}17.23 \pm 0.82^{\mathrm{Ba}} \\
2.80 \pm 0.16^{\mathrm{Bb}} \\
1.80 \pm 0.38^{\mathrm{Aa}}\end{array}$ & $\begin{array}{c}18.84 \pm 0.94^{\mathrm{Ba}} \\
3.31 \pm 0.50^{\mathrm{Ab}} \\
0.70 \pm 0.20^{\mathrm{Ba}}\end{array}$ & $\begin{array}{l}20.36 \pm 1.81^{\mathrm{Ba}} \\
2.61 \pm 0.44^{\mathrm{Bab}} \\
1.62 \pm 0.55^{\mathrm{Aab}}\end{array}$ & $\begin{array}{c}10.36 \pm 0.46^{\mathrm{Ab}} \\
0.99 \pm 0.21^{\mathrm{Bc}} \\
4.45 \pm 0.48^{\mathrm{Bbc}}\end{array}$ & $\begin{array}{l}5.22 \pm 1.26^{\mathrm{Ad}} \\
0.67 \pm 0.29^{\mathrm{Ac}} \\
6.90 \pm 1.30^{\mathrm{Ac}}\end{array}$ \\
\hline
\end{tabular}

The superscript letters indicate the statistical significance, identical letters identify means that are not significantly different; different letters identify statistically different means $(\mathrm{P}<0.05)$. Upper case letters indicate the comparison between autotrophic and heterotrophic conditions. 


\section{Conclusions}

In conclusion, the pigment and amino acid contents in Galdieria sulphuraria were profoundly dependent on the nitrogen status of the cells. Relevant differences were found between cells cultured in autotrophy or in heterotrophy, where the energy required for growth and metabolism depended on photosynthesis, or only on the respiration of added organic substrate, as in heterotrophic cells.

\section{References}

1. Juneja A, Ceballos RM, Murthy GS. Effects of Environmental Factors and Nutrient Availability on the Biochemical Composition of Algae for Biofuels Production: A Review. Energies 2013;6:4607-38.

2. Carfagna S, Salbitani G, Bottone C, et al. Cross-Effects of Nitrogen and Sulphur Starvation in Chlorella sorokiniana 211/8K. Nat Res 2015;6:221-29.

3. Richaud C, Zabulon G, Joder A, Thomas JC. Nitrogen or sulfur starvation differentially affects phycobilisome degradation and expression of the nblA gene in Synechocystis strain PCC 6803. J Bacteriol 2001;183:2989-94.

4. Pisal DS, Lele SS. Carotenoid production in Dunaliella salina. Indian $\mathrm{J}$ Biotechnol 2003;4:476-83.

5. Agirman N, Cetin AK. Effects of nitrogen starvations on cell growth, protein and lipid amount of Chlorella vulgaris. Fresen Environ Bull 2015;24:3643-48.

6. Benavente-Valdés JR, Aguilar C, Contreras-Esquivel JC, et al. Strategies to enhance the production of photosynthetic pigments and lipids in chlorophyceae species. Biotechnol Rep (Amst) 2016;10:117-125.

7. Merzlyak MN, Chivkunova OB, Gorelova OA, et al. Effect of nitrogen starvation on optical properties, pigments, and arachidonic acid content of the unicellular green alga Parietochloris incisa (Trebouxiophyceae, Chlorophyta). J Phycol 2007;43:833-43.

8. Salbitani G, Vona V, Bottone C, et al. Sulfur deprivation results in oxidative perturbation in Chlorella sorokiniana (211/8k). Plant Cell Physiol 2015;56: 897-905.

9. Chokshi K, Pancha I, Ghosh A, Mishra S. Nitrogen starvation-induced cellular crosstalk of ROS-scavenging antioxidants and phytohormone enhanced the biofuel potential of green microalga
Acutodesmus dimorphus. Biotechnol Biofuels 2017;10: 60.

10. Bottone C, Camerlingo R, Miceli R, et al. Antioxidant and anti-proliferative properties of extracts from heterotrophic cultures of Galdieria sulphuraria. Nat Prod Res 2019;15:1-5.

11. Schönknecht G, Chen WH, Ternes CM, et al. Gene transfer from bacteria and archaea facilitated evolution of an extremophilic eukaryote. Science 2013;339:1207-10.

12. Iovinella M, Carbone DA, Cioppa D, et al. Prevalent $\mathrm{pH}$ Controls the Capacity of Galdieria maxima to Use Ammonia and Nitrate as a Nitrogen Source. Plants 2020; doi: 10.3390/plants9020232.

13. Oesterhelt C, Schmälzlin E, Schmitt JM, Lokstein H. Regulation of photosynthesis in the unicellular acidophilic red alga Galdieria sulphuraria. Plant J 2007;51:500-11.

14. Sinetova MP, Markelova AG, Los DA. The Effect of Nitrogen Starvation on the Ultrastructure and Pigment Composition of Chloroplasts in the Acidothermophilic Microalga Galdieria sulphuraria. Russ J Plant Physiol 2006;53:153-62.

15. Eriksen NT. Production of phycocyanin-a pigment with applications in biology, biotechnology, foods and medicine. Appl Microbiol Biotechnol 2008;80:1-14.

16. Carfagna S, Landi V, Coraggio F, et al. Different characteristics of C-phycocyanin (C-PC) in two strains of the extremophilic Galdieria phlegrea. Algal Res 2018;31:406-12.

17. Carfagna S, Salbitani G, Bottone C, Vona V. Galdieria sulphuraria as a possible source of food colorant. J Nutr Ecol Food Res 2016;3:78-81.

18. Carfagna S, Napolitano G, Barone D, et al. Dietary supplementation with the microalga Galdieria sulphuraria (Rhodophyta) reduces prolonged exercise-induced oxidative stress in rat tissue. Oxid Med Cell Longev 2015; Article ID 732090.

19. Kuddus M, Singh P, Thomas G, AlHazimi A. Recent developments in production and biotechnological application of C-Phycocyanin. Biomed Res Int 2013:742859.

20. De Morais MG, da Fontoura Prates D, Moreira JB et al. Phycocyanin from microalgae: properties, extraction and purification, with some recent applications. Industrial Biotech 2018;14:30-37.

21. Mulders KJM, Lamers PP, Martens DE, Wijffels RH. Phototrophic pigment production with microalgae: biological constraints and opportunities. J Phycol
2014;50:229-42.

22. Vona V, Di Martino Rigano V, Andreoli $\mathrm{C}$, et al. Comparative analysis of photosynthetic and respiratory parameters in the psychrophilic unicellular green alga Koliella antarctica, cultured in indoor and outdoor photo-bioreactors. Physiol Mol Biol Plants 2018;24:1139-46.

23. Salbitani G, Barone CMA, Carfagna S. Effect of bicarbonate on growth of the oleaginous microalga Botryococcus braunii. Int J Plant Biol 2019;10:8273.

24. Salbitani G, Del Prete S, Bolinesi F, et al. Use of an immobilized thermostable $\alpha$-CA (SspCA) for enhancing the metabolic efficiency of the freshwater green microalga Chlorella sorokiniana. J Enzyme Inhib Med Chem 2020;35: 913-20.

25. Salbitani G, Cipolletta S, Vona V, et al. S. Heterotrophic cultures of Galdieria phlegrea shift to autotrophy in the presence or absence of glycerol. J Plant Growth Regul 2020; DOI: 10.1007/s00344-020-10109-0.

26. Sarkar D, Shimizu K. An overview on biofuel and biochemical production by photosynthetic microorganisms with understanding of the metabolism and by metabolic engineering together with efficient cultivation and downstream processing. Bioresour Bioprocess 2015;2:17.

27. Dubois F, Tercé-Laforgue T, GonzalezMoro MB, et al. Glutamate dehydrogenase in plants: is there a new story for an old enzyme? Plant Physiol Biochem 2003;41:565-76.

28. Imamura S, Terashita M, Ohnuma $\mathrm{M}$ et al. Nitrate assimilatory genes and their transcriptional regulation in a unicellular red alga Cyanidioschyzon merolae: Genetic evidence for nitrite reduction by a sulfite reductase-like enzyme. Plant Cell Physiol 2010;51:707-17.

29. Vona V, Di Martino Rigano V, Esposito $\mathrm{S}$, et al. Growth, photosynthesis, and respiration of Chlorella sorokiniana after $\mathrm{N}$-starvation. Interactions between light, $\mathrm{CO} 2$ and NH4+ supply. Physiol Plant 1999;105:288-93.

30. Mark NM, Olga B, Chivkunova OA, et al. Effect of nitrogen starvation on optical properties, pigments, and arachidonic acid content of the unicellular green algae. J Phycol 2007;43:833-43.

31. Hockin NL, Mock T, Mulholland F, et al. The Response of Diatom Central Carbon Metabolism to Nitrogen Starvation Is Different from That of Green Algae and Higher Plants. Plant Physiol 2012;158:299-312.

32. Aremu AO, Neményi M, Stirk WA, et al. Manipulation of nitrogen levels and 
mode of cultivation are viable methods to improve the lipid, fatty acids, phytochemical content, and bioactivities in Chlorella minutissima. J Phycol 2015;51:659-69.

33. Allen MB. Studies with Cyanidium caldarium an anomalously pigmented chlorophyte. Archiv Microbiol 1959;32:270-77.

34. Carfagna S, Salbitani G, Vona V, Esposito S. Changes in cysteine and $\mathrm{O}$ acetyl-L-serine levels in the microalga Chlorella sorokiniana in response to the S-nutritional status. J Plant Physiol 2011;168:2188-95.

35. Carfagna S, Lanza N, Salbitani G, et al. Physiological and morphological responses of Lead or Cadmium exposed Chlorella sorokiniana 211-8K
(Chlorophyceae). SpringerPlus 2013;2:147-54.

36. Stadnichuk IN, Rakhimberdieva MG, Bolychevtseva YV, et al. Inhibition by glucose of chlorophyll a and phycocyanobilin biosynthesis in the unicellular red alga Galdieria partita at the stage of coproporphyrinogen III formation. Plant Sci 1998;136:11-23.

37. Perez-Garcia O, Escalante FME, deBashan LE, Bashan Y. Heterotrophic cultures of microalgae: metabolism and potential products. Water Res 2011;45:11-36.

38. Manning M, Strain HH. Chlorophyll d, a green pigment of red alga. J Bio Chem 1943;151:1-19.

39. Sloth JK, Wiebe MG, Eriksen NT. Accumulation of phycocyanin in het- erotrophic and mixotrophic cultures of the acidophilic red alga Galdieria sulphuraria. Enzyme Microb Technol 2006;38:168-75.

40. Schwarz R, Grossman AR. A response regulator of cyanobacteria integrates diverse environmental signals and is critical for survival under extreme conditions. Proc Natl Acad Sci USA 1998;95:1108-13.

41. Glass AD, Britto DT, Kaiser BN, et al. The regulation of nitrate and ammonium transport systems in plants. J Exp Bot 2002;53:855-64.

42. Di Martino Rigano V, Vona V, Esposito $\mathrm{S}$, et al. The physiological significance of light and dark NH4+ metabolism in Chlorella sorokiniana. Phytochem 1998;47:177-81. 